\title{
About that known as Mexican anthropology: nostalgia for a knowable community in Mexico City
}

\author{
Ricardo F. Macip ${ }^{1}$
}

Published online: 27 July 2017

(C) The Author(s) 2017. This article is an open access publication

The fiftieth anniversary of the original impression of De eso que llaman Antropología Mexicana (Warman et al. 1969) is now approaching. As with most canonized texts, this one is doomed to be the recipient of the overenthusiastic praise that comes with being frequently cited but seldom read. Before trying to assess some of the book's merits, a little framing is called for. First of all, I want to note that the book was reprinted in 2002 in its original Spanish and that there has been no translation of it whatsoever. The Committee of Students' Publications of the National School of Anthropology and History (Mexico City), which holds the rights to the first edition, also issued the one in 2002 (Warman et al. 2002). Another edition appeared shortly after the original in the collection "Culture to People" (La Cultura al Pueblo) put out by the publisher Nuestro Tiempo in 1970. Therefore, discussion of De eso que llaman Antropología Mexicana has been primarily a "Mexican affair." I mention all this because I sustain that a generational reading is in order for its appreciation.

Before discussing the value of again reprinting De eso... in the future or aiming for translation into another language, let me state that it is the 2002 reprint of the book that makes it worth revisiting. Between 1969 and 2002 and from 2002 to the present, a lot has changed in Mexico as a political formation and society. Anthropology is no exception. The (revolutionary) state party that ruled for over 70 years was ousted from power (in 2000) without recourse to violence, the generation marked by the 1968 student massacre in Mexico City came to exercise full political power within the same structures of that party and bureaucracy and the teaching of anthropology passed from a handful of universities and institutions in Mexico City to a large number of institutions dispersed around the country and staffed by numerous professionals, many of whom do not know one other. All those changes ought to be considered as healthy developments, in that one is no longer tied to hubristic ideas of patrimony and centralization.

Ricardo F. Macip

keropedo@yahoo.com

1 MASC-ICSyH-BUAP, Calle 4 Sur 104 Centro Histórico, C.P. 72000 Heróica Puebla de Zaragoza, Puebla, Mexico 
In what some cultural historians (Joseph et al. 2001) have identified as a "golden age" (1940-1968) of modernization, culture industries and dialog with the world, others have viewed as an insufferable gray horizon of mediocrity (Bartra 1993, 13). This "golden age" corresponded to the apogee of the state party and the way it employed every available national resource as a motor of modernization, industrialization, and urbanization in Mexico. This included all professions. Anthropology was drawn into this process as the discipline in charge of handling and managing Indians and integrating them into "the nation." It was in opposition to this mandate that a coterie of anthropologists wrote in De eso que llaman Antropología Mexicana. Important for my discussion here is the manner in which generations between 1940 and 1968 were formed in the context of an expansionist juggernaut that menaced with its flattening powers all that stood in its way. Whether the juggernaut was as menacing and the flattening as severe as people once projected has now become a matter of contention. What seems unquestionable is that most people living and working in Mexico at the time considered it to be so.

De eso que llaman Antropología Mexicana was considered a tour de force critique aimed at exposing and enlarging cracks in the system that subordinated "Mexican anthropology" to state policies as part of the governmental apparatus. The official policy of integrating indigenous populations aimed at their acculturation through different means. Of course, they had been integrated as labor forces and labor reserves since colonial times, but the middle part of the twentieth century presented the opportunity to accelerate their proletarianization. By presenting a thorough critique of the contradictions in the process, the authors helped open a new generational horizon of counter-politics (as defined by Smith 2014). From 1968 to 1994, cultural and political confrontations in Mexico aimed at expanding the spaces outside of state control. Anthropology became implicated in this process through the creation of new institutions and the extension of the discipline to new regions throughout the country. The period began with the student massacre of 1968 and ended in 1994 with the contradictory integration of the North American common market (through NAFTA) and rise of the Zapatista insurgency.

The Mexican democratic transition-which culminated in 2000 with the victory of an opposition candidate to the presidency — has been marked by its odd relation with the neoliberal order under NAFTA, on the one hand, and the assertion through political activism of a "civil society," on the other. The multiplicity of demands (Laclau 2005) of this civil society were not all new; some had been nursed since 1968 indeed, but they coalesced behind (albeit not exclusively) Zapatismo. Once the state party (PRI) found itself out of the presidency (in 2000), a renewed "narco" civil war, fought from the states against the federation and from the corporations against neoliberal reforms, gradually but mercilessly engulfed the country. Given its proxy (narco) civil war, Mexico has been under a permanent state of exception since 2006.

The 2002 reprint of the book led me to take this detour because I consider it important to keep in mind the different structures of feeling (Williams 1977) of the diverse audiences to which the book speaks and with which it dialogs. In the years that have transpired since the book's initial publication in 1969, the country has changed radically and, as I noted above, anthropology has changed with it. In the past, the Escuela Nacional de Antropología e Historia (National School of Anthropology and History) and Mexico City exercised a virtual monopoly in the training and employment of anthropologists. Currently, the capital contains five doctoral programs in anthropology plus a growing number of M.A. and undergraduate programsmaking Mexico City the site of the heaviest concentration of anthropology programs in the world. However, beginning in the 1980s and increasingly since, Mexico City has been forced to share the table and engage with a growing and diversified array of academic groups and trends 
of anthropology that are not staffed exclusively with or dominated by its graduates. What passed as Mexican anthropology in De eso que llaman Antropología Mexicana was a knowable community (Williams 1973, 165) able to celebrate its nostalgia and involution. With the growth of anthropology and the extension of anthropological training to the provinces, that is no longer the case.

There is no shortage of books published in English to which De eso que llaman Antropología Mexicana has been compared. During my formation as an undergraduate (1988-1993) in Mexico, Anthropology and the Colonial Encounter, edited by Talal Asad in 1973, and Decolonizing Anthropology, edited by Faye Harrison in 1991, were used to highlight its shortcomings as a critical project. Reading them together, as elements of contrast, the provincialism and deficiencies of De eso que llaman Antropología Mexicana became evident. The different conditions under which each project was produced underlined the narrow contours of thinking the world from Mexico City. The scope, breath, and depth of the latter were all concentrated on one dimension of applied anthropology that would not by any stretch of the imagination be considered a "school" of thought, much less a methodology, anywhere outside Mexico. Moreover, the contribution this Mexican anthropology made to the broader anthropological literature was scant. Yet before delving into those comparisons and their residual excesses, let us consider an odd feature that marked both the original edition as well as the later reprint: the lack of an introduction.

The lack of an introductory essay - the Nuestro Tiempo edition includes a presentation that says little more than that anthropology is relevant to the resolution of great national problems - has the effect of forcing readers interested in understanding how the papers were written and the decision to print them together to recur to anecdote, oral tradition, common sense, and the cult of the elders. Were the articles products of a conference or political event or did they involve an intervention on the part of a group of young guns intent on stirring up student dissatisfaction? Outside gossip and "myth," there is no way to know. Given that the articles employ at least two different formats for citation and style, respected in the reprint, I suggest that the sloppiness indicates political urgency in the original edition and respect for the poetry "of the times" in its reprint.

The common thread that runs throughout the book is ambiguity. On the one hand, all the articles push for a critical social anthropology, clearly separated from ethnology and archeology by the imperative that anthropologists go, see, document, question and debate beyond Indigenismo. Indigenismo reduced a potentially vibrant and promising discipline to a series of procedures that could be transmitted to technicians in order to ensure the complete domination of indigenous peoples by an illegitimate state. All five articles deliver the above message loud and clear. At the same time, they leave almost untouched the pretension and shame that this same Indigenismo is what passed then (and now) for Mexican anthropology. Rejecting "Mesoamerican nationalism" and state-sponsored anthropology for their noxious excesses is one thing; to evacuate Mexican anthropology of meaning is quite another. The fate of Mexicaness is left to the reader to figure out. Divorcing anthropology from governmental direction is the book's singular merit. But the authors failed to explain what a specifically Mexican anthropology might look like.

Warman would eventually rewrite his "sweeping and scouring" notes in a masterful essay ("Indigenist Thought") published in English in 1982 in a collection of Indigenous Anthropology in Non-Western Countries edited by Hussein Fahim. There he would rub elbows and schmooze (figuratively) with Asad and others, moving his anthropology away from Indigenismo as a state practice of control and in the direction of a full-fledged anthropological 
tradition of elaborated thought. Also in the eighties, Guillermo Bonfil Batalla would "vicariously" rewrite his essay in the milestone book México profundo (1987) with all the mysticism of his favorite keyword (vicarial-vicarious). He used the semantic banner and floating signifier less often than before, but by then he had mastered its Christian meaning of atoning for others. By 1994, large groups of students were eager to follow his call by adopting the Zapatistas as banner, cause and specific form of melancholy (Bartra 2002). Those two authors offered two clearly contrasting paths for future generations regarding how to deal with the "philanthropic ogre," which is how Octavio Paz nicknamed the fetishized and reified state as an actor simultaneously brutal-demented as a foe and generous-rational as a benefactor. Both pieces retained all the hubris of the articles that preceded them in De eso.... More nuanced than those of Warman and Bonfil, but condemned to the conjuncture in which they were written, are the articles by Nolasco, Olivera and Valencia. They dealt with the relation between applied anthropology and Indigenismo and carried out an institutional diagnosis of how and why anthropology was more a governmental than an academic practice, as well as how it conditions the formation of new generations. However, they also insinuated that there is something specifically Mexican about the anthropology produced in Mexico.

Reading the book and nothing else produced in Mexico (by either Mexican citizens and foreign residents based there, on the one hand, or the flocks of foreigners that have used Mexico as their field sites, summer schools or vocational ethnoscapes, on the other), it becomes clear that for as long as the discipline has existed, there has been vigorous dialog between professionals in anthropology in Mexico and anthropologists representing at least three linguistic traditions. The dialogs have varied according to topics and sub-disciplines, fashions, and debates, but English, German, and French authors, canons and obsessions have been appropriated for explaining mostly but not exclusively indigenous populations and comparing civilizations in Mexico. It is, rather, the nature of the dialog that matters. At some points, specific literatures seem to take over the main debate and even what the discipline itself may be, ranging from the simple translation of concepts (such as "transnationalism") to be filled with "local" ethnographic descriptions to unmitigated destruction and banning of entire schools of thought (as has been the case with Marxism in Mexico City since the 1990s). Yet anthropologists working in and from Mexico have always contributed to anthropology. It is the nature of that contribution that must be questioned; it should not be fetishized within the current nonsense of "southern" anthropologies or anthropologies of the world (Putumayo style).

The niche marketing of anthropology searching for brand-recognition is part of a larger trend. As with the other culture industries examined by Joseph et al. (2001), the temptation to label something as Mexican is not new. Rock/cinema/literature need to create the illusion of a niche in order to morph into culture industries with an expanding market that provides them the financial independence that is a necessary condition for them to liberate themselves from subordination to the state that comes with state subsidies. So far, they have failed miserably. Among the art forms developed in the twentieth century, only professional wrestling, which competes well against its Unitedstatesian and Japanese counterparts, has achieved that independence (Levi 2008; Macip 2016).

Anthropology is no art form. Treating it as such would be as preposterous as taking seriously the existence of a "Mexican physics" just because physics is taught, researched, and debated in Mexican institutions by Mexican physicists. To insist on the particularities of "Mexican" anthropology is pure nonsense. Even Indigenismo was not monopolized by Mexican institutions; it was also debated by Brazilian and Peruvian anthropologists, among 
others. But the counter-politics of the 1968-1994 generational cohorts sank in the wake of the 1989 International Labor Organization Convention 169 "Concerning Indigenous and Tribal Peoples in Independent Countries." Allegedly granting autonomy to indigenous peoples, the convention strengthened forms of economic and political domination, which should not be surprising to anyone. Indigenismo has moved from its botched integration into the marketing and management of allegedly irreducible differences and made space for the emergence of ethnic alienation with different purposes and effects. It would be a mistake to read in this a Mexican component, for the convention was widely adopted in Latin America in the 1990s (with Uruguay and Cuba as the only exceptions), and anyway, the marketing of ethnic difference is a global phenomenon (Comaroff and Comaroff 2009). However, precisely because anthropological debates rage in Mexico with the "scouring and annoying" force decried by Warman, it is worthwhile to engage them beyond chauvinistic atavisms (Bartra 2002; Vazquez León, 2016).

As the above suggests, the "Mexican Anthropology" in the title of De eso que llaman Antropología Mexicana refers to the anchor of a ship wrecked on its maiden voyage. It refers to a particular nostalgia for a knowable community, for the good old days when anthropologists ran into each other at the National Museum, government offices, cafes, and similar venues in southern areas of Mexico City. Gratefully, neoliberalism and its civil war freed us all from such parochial misery.

Open Access This article is distributed under the terms of the Creative Commons Attribution 4.0 International License (http://creativecommons.org/licenses/by/4.0/), which permits unrestricted use, distribution, and reproduction in any medium, provided you give appropriate credit to the original author(s) and the source, provide a link to the Creative Commons license, and indicate if changes were made.

\section{References}

Asad, Talal, ed. 1973. Anthropology and the Colonial Encounter. Atlantic Highlands, NJ: Humanities Press.

Bartra, Roger. 1993. Oficio Mexicano. Mexico: Grijalbo.

Bartra, Roger. 2002. Blood, Ink and Culture. Miseries and Splendors of the Post-Mexican Condition. Durham: Duke University Press.

Bonfil Batalla, Guillermo. 1987. México profundo. Mexico: SEP.

Comaroff, John, and Jean Comaroff. 2009. Ethnicity Inc. Chicago: University of Chicago Press.

Harrison, Faye, ed. 1991. Decolonizing Anthropology: Moving Further toward an Anthropology for Liberation. Washington, DC: American Anthropological Association.

Joseph, Gilbert, Anne Rubenstein, and Eric Zolov, eds. 2001. Fragments of a Golden Age. Durham: Duke University Press.

Laclau, Ernesto. 2005. La razón populista. Mexico: Fondo de Cultura Económica.

Levi, Heather. 2008. The World of Lucha Libre. Durham: Duke University Press.

Macip, Ricardo. 2016. Pankration: the Spectacle of Masculinity in Mexican Political Culture. In Eduardo González Castillo, Jorge Pantaleón and Nuria Carton de Grammont,Politics, culture and economy in popular practices in the Americas, eds. 127-53. New York: Peter Lang.

Smith, Gavin. 2014. Intellectuals and (Counter-) Politics. NY: Berghahn.

Vazquez León, Luis. 2016. Multiculturalism as a Political Weapon: the Use and Abuse of the Concept of 'Pueblo Originario’ in Agrarian Conflicts in Michoacan, Mexico. In The Crisis of Multiculturalism in Latin America, ed. David Lehmann, 35-73. London: Palgrave.

Warman, Arturo, M. Nolasco, G. Bonfil, M. Olivera, and E. Valencia. 1969. De eso que llaman antropología Mexicana. Mexico: Comité de Publicaciones de los Alumnos de la Escuela Nacional de Antropología e Historia.

Warman A., M. Nolasco, G. Bonfil, M. Olivera and El Valencia. 2002 [1969]. De eso que llaman antropología mexicana, México, Comité de Publicaciones de los Alumnos de la ENAH, 2002.

Williams, Raymond. 1973. The Country and the City. New York: Oxford University Press.

Williams, Raymond. 1977. Marxism and Literature. New York: Oxford University Press. 